\title{
FEMALE LABOR SUPPLY: WHY IS THE US FALLING BEHIND?*
}

\author{
Francine D. Blau \\ Cornell University, NBER, IZA and CESifo \\ Lawrence M. Kahn \\ Cornell University, IZA, CESifo, and NCER (Australia)
}

November 2012

\begin{abstract}
*For presentation at the American Economic Association meetings, San Diego, January 2013. The authors are grateful to Bruce Sacerdote for advice, and to Gary Cohen and Jason Cook for excellent research assistance and to Cornell University for financial support.
\end{abstract}




\title{
FEMALE LABOR SUPPLY: WHY IS THE US FALLING BEHIND?
}

\begin{abstract}
In 1990, the US had the sixth highest female labor participation rate among 22 OECD countries. By 2010, its rank had fallen to $17^{\text {th }}$. We find that the expansion of "family-friendly" policies including parental leave and part-time work entitlements in other OECD countries explains about $29 \%$ of the decrease in US women's labor force participation relative to these other countries. However, these policies also appear to encourage part-time work and employment in lower level positions: US women are more likely than women in other countries to have full time jobs and to work as managers or professionals.
\end{abstract}

(JEL J16, J22)

Keywords: gender, labor supply. 
In 1990, US women had one of the highest labor force participation rates among Western, economically advanced nations. By 2010, however, women in most other economically advanced countries had surpassed those in the United States in their participation in the labor force. These trends are especially salient to recent discussions in the United States of an "opt-out revolution” in which women are said to have expressed a desire to curtail their work outside the home (Belkin 2003). While the notion that there has actually been a significant labor force withdrawal of women is controversial, it is clear that women's overall labor force participation in the United States has not changed appreciably since the mid-1990s, in marked contrast to the robust growth of preceding decades (Blau, Ferber and Winkler 2010). Unlike the United States, most other economically advanced nations have enacted an array of policies designed to facilitate women's participation in the labor force, and such policies have on average expanded over the last 20 years relative to the United States. In this paper, we study the role of such policies in explaining the decline in US women's relative position in labor force participation internationally and discuss some possible unintended side effects of these policies, including a reliance on part-time employment for women and lower female representation in high level positions.

\section{The Facts: Women's Labor Force Outcomes and Work-Family Policies}

Table 1 shows male and female labor force participation rates (LFPRs) by country for 1990 and 2010 for 25-54 year olds (to abstract from schooling and retirement decisions). In 1990, US women's LFPR of 74.0 percent was the sixth highest among the 22 countries. By 2010, US women's LFPR had risen slightly to 75.2 percent; however, on average women in the other countries had dramatically raised their LFPR from 67.1 to 79.5 percent-not only catching up to but also surpassing the United States. As of 2010, US women ranked $17^{\text {th }}$ of 22 , a stunning reversal. Labor force participation rates declined for men, both in the United States and in other countries, over this period and the decrease was somewhat larger for US men. Thus, their relative LFPR also fell, but less dramatically than women's, with their ranking declining from $14^{\text {th }}$ to $22^{\text {nd }}$. The upshot of Table 1 is that the gender gap in LFPRs fell moderately in the United 
States, from 19.4 percentage points in 1990 to 14.1 in 2010; in contrast, outside the United States, the gender gap fell by much more, from 26.9 to 13.0 percentage points. Using 2007 as the endpoint (i.e. before the recent recession) leads to the same overall conclusion about the reversal in US women's relative position.

Table 2 summarizes international differences in some key policies that we expect to influence especially women's labor supply, as well as in the incidence of part-time work (defined by the OECD as less than 30 hours per week). The table presents data for the United States and a non-US Average based on 16 other countries for which we have data in both 1990 and 2010 . The policies include both laws concerning parental leave entitlements and part time-work, as well as public expenditures on child care.

First, most countries provide workers with an entitlement to parental leave as well as mandated pay during such periods. The US mandate of up to 12 weeks of unpaid leave dates to the passage of the Family and Medical Leave Act of 1993 (Blau, Ferber and Winkler 2010). However, entitlements in other countries, generally predated the US, were longer, usually paid, and expanded on average by more during the 1990 -2010 period. $^{1}$ Parental leave potentially has complex effects on labor supply (see, for example, Ruhm 1998 or Waldfogel 1998). On the one hand, it is an entitlement that one can only qualify for by having a job in the first place. Along the same lines, by giving workers the right to their job back after taking the leave, the entitlement raises the job prospects of those who have left the labor force to take care of children. These effects suggest that parental leave would increase women's LFPRs. ${ }^{2}$ On the other hand, parental leave mandates may encourage women to stay out of the labor force longer than they otherwise would. And such mandates may raise the expected cost of employing women of childbearing

\footnotetext{
${ }^{1}$ Coverage is also likely more limited in the United States than elsewhere. The FMLA applies only to employees who have been with the same employer for at least one year and worked at least 1,250 hours; establishments with less than 50 workers are excluded. It is estimated that the FMLA covers just under 50 percent of private-sector workers (Waldfogel 2001). Some states mandate more generous benefits and some employers provide more than the statutory minimum.

${ }^{2}$ There is also a measurement issue in that individuals out on parental leave are counted as employed (with a job but not at work). Ruhm (1998) finds indirect evidence that such effects can account for between one quarter and one half of the positive impact of paid leave on women's employment-to-population ratios.
} 
age, since they are most likely to use the entitlement, thus, potentially lowering their wages and possibly deterring employers from hiring them. Thus, parental leave has theoretically ambiguous effects on women's labor supply, although Ruhm (1998) finds a positive effect based on eight countries.

Second, between 1990 and 2010, five countries enacted laws giving workers the right to demand a change to a part-time work schedule without exception. Moreover, while in 1990 only two of the 16 non-US countries shown in Table 2 forbade discrimination against part-time workers, by 2010, 12 had such legislation. Workers in the United States did not have such protections. We expect these rights for part-time workers to increase the supply of workers, particularly women, to part-time jobs. Of course, to the extent that these laws raise the cost of employing part-time workers, they may reduce employers' incentives to offer part-time jobs. These employer demand effects may indirectly reduce labor force participation. The net impact of part-time worker protections on LFPRs is thus theoretically uncertain. Interestingly, Table 2 shows that part-time work among women is much more prevalent in other countries than in the United States, while differences among men are small, although the incidence for both men and women appears to be stable over time.

Third, most countries have publicly provided child care services. According to the OECD, the United States does not provide these services, while, on average, they have expanded slightly in the other countries, as shown in Table $2 .^{3}$ We expect child care availability to raise women's LFPRs by reducing the cost of working outside the home. This expectation is less theoretically ambiguous than it is for part-time work entitlements and family leave because publicly provided child care does not raise employer costs of employing women the way a part-time entitlement

\footnotetext{
${ }^{3}$ We measure child care spending as a fraction of GDP (to abstract from differences in economic development) per child ages 0-4. Standardizing by the approximate size of the child care clientele provides a measure of the relative generosity of such programs. Nickell (1997) uses a similar concept in measuring the generosity of active labor market policies by standardizing by the number of unemployed workers. While the United States does offer a child care tax credit, data from the Internal Revenue Service suggest that the total amount of such credits is too small to change the US's low ranking in publicly provided child care. See http://www.irs.gov/taxstats/indtaxstats/article/0,id=134951,00.html . The US also provides some childcare grants and expenditures targeted on the low income population.
} 
might. In addition, as noted, family leave makes it easier to at least temporarily leave the labor force and also may increase employer incentives to discriminate against women, while child care services may actually enhance the perceived reliability of women workers in the eyes of employers.

The policy data on which Table 2 is based show that most other countries have enacted parental leave, part-time work, and child care policies that are more extensive than in the United States, and the gap has grown over time. This growing US-other country gap in the policy environment can potentially help explain the more rapid rise in female LFPRs in other countries than in the United States and, in the next section, we investigate the degree to which this is true.

\section{Accounting for the US Decline in Relative Female Labor Force Participation Rates}

To study whether the changing policy environment for balancing work and family has influenced the trends in Table 1, we performed linear regression analyses of women's LFPRs, men's LFPRs, the male-female difference in LFPRs, and the log of the male-female ratio in LFPRs. We used annual data by country for the 1990-2010 period or the 1990-2007 period depending on data availability (childcare data are only available for the latter period). Key explanatory variables include the policies shown in Table 2 as well as the male unemployment rate (to control for business cycle effects), and a full set of year and country dummy variables. Finally, standard errors were clustered at the country level. (See Table 2 for data sources. ${ }^{4}$ )

Note that we do not include education levels or GDP per capita since these may be endogenous with respect to women's labor supply. Specifically, women's schooling levels in

\footnotetext{
${ }^{4}$ The Comparative Family Policy Database used in our analyses coded the United States as having no "Parental Leave” during 1960-2010 but as having instituted "Child Care Leave” of 12 unpaid weeks in 1993. In our basic analyses, we have credited the United States with having Parental Leave of 12 weeks starting in 1993 with the passage of the Family Medical Leave Act, although the basic results were very similar when we used the Database's value of zero for the United States. The Database also includes two additional policy variables which we have not used in our basic analyses: Maternity Leave and Child Care Leave. As described in the documentation, the Maternity Leave entitlement measure is often folded into the Parental Leave variable; similarly Child Care Leave is sometimes a supplement to Parental Leave and other times takes the form of a subsidy to use a child care center. Because of these ambiguities and the possibility of double counting, we do not control for these variables in our basic regressions, but when we did add them, the basic decomposition results (see Table 4 below) were very similar.
} 
part reflect their labor force plans, and there is likely to be a mechanical effect of labor supply on GDP per capita. Moreover, while previous research (Goldin 1995; Mammen and Paxson 2000) documented a U-shaped effect of economic development on female labor supply, our sample consists of developed economies during a very recent period in history (1990-2010); these findings may therefore be less relevant to our study than one encompassing a longer time span or set of countries at different stages of economic development. Our estimates should be seen as reduced forms of the effect of the policies mentioned above.

Since we have included country dummy variables, the impact of policy is identified through within-country changes in laws, which may occur infrequently. Thus, it may be difficult to detect effects of policies in such a framework. Nonetheless, including country fixed effects is important because there are likely to be omitted factors affecting labor supply that are specific to individual countries, including religion and culture, the taxation system, other labor market interventions, and women's relative wages. ${ }^{5}$ For example, while most countries tax income on an individual basis, the US income tax is virtually unique in treating the income of married couples jointly, potentially raising the marginal tax rate of secondary earners (Gruber 2011, pp. 551-2). OECD data indicate that the taxation unit in nearly all of the countries studied here did not change during the 1990-2010 period, implying that our control for country fixed effects can account for these intercountry differences (OECD, Taxing Wages, various issues). ${ }^{6}$ While country fixed effects are useful in controlling for differences across countries in unmeasured factors, we acknowledge that an exogenous increase in women's labor supply could lead to demands for legislation increasing parental leave entitlements, part-time worker protections, and child care provision. Thus, while it is plausible that such policies could affect women's labor supply, the laws themselves may well be endogenous, and we are therefore cautious about interpreting our estimates of the effects of the laws causally.

\footnotetext{
${ }^{5}$ Unfortunately, our data were not able to support the inclusion of country-specific time trends.

${ }^{6}$ Country fixed effects also adjust, at least in part, for intercountry differences in tax rates; for data on rates, see http://www.oecd.org/ctp/taxpolicyanalysis/oecdtaxdatabase.htm\#B_PersonalTaxes.
} 
Table 3 presents the results of the analyses of the LFPRs of men and women, as well as of the gender differences and ratios. Panel A, which covers 1990-2010, includes the parental leave policy and part-time protection variables; Panel B, which covers 1990-2007, adds public child care spending to the set of explanatory variables. The results for the leave and part-time policies are similar in Panels A and B; each policy has a positive effect on both men's and women's LFPRs and a negative effect on the male-female difference or the log of the male/female ratio of LFPRs. The policy variables are highly significant as a group for both men and women in all specifications. The results for men may indicate a true effect of these policies on male LFPRs or may be due to a correlation of the policies with general factors raising LFPRs in the economy. Of importance here, however, is that the coefficients are much larger for women than men, leading to the negative signs in the models estimating the male-female gap (or ratio) in LFPRs. The larger size of the female effects suggests that our policy variables do reflect, at least in part, gender-related factors affecting labor supply rather than simply standing in for economy-wide work propensities common to both sexes. The results for child care spending (Panel B) indicate that it has an insignificantly negative effect on men's LFPRs and an insignificantly positive effect on women's LFPRs. (All policies, now including child care spending, remain significant as a group. $)^{7}$

The regression results in Table 3 suggest that these family-friendly policies increase female labor force participation and reduce the gender gap in LFPRs. We now examine the magnitude of the effect on female labor force participation and ask whether the expansion of these policies in countries other than the United States can explain the reversal of US women's relative position in LFPRs among economically advanced countries. Table 4 performs this analysis by simulating US women's LFPR using the non-US average levels of these policies shown in Table 2. Again, Panels A and B refer to models with and without the child care spending variable in the model. The simulation results are very similar.

\footnotetext{
${ }^{7}$ Results for the leave and part-time policies for the 1990-2007 period (excluding child care spending) are similar to those reported in Panel A for the 1990-2010 period.
} 
Looking at Panel A, the simulation shows that with the non-US policies in 1990, US women's LFPR would have been 77.0 percent instead of its actual level of 74.0. By 2010, with the expansion of these policies outside the United States, giving US women the other countries' average policy levels would have raised their LFPR to 82.0 percent compared to its actual value of 75.2 percent, a substantial 6.8 percentage point increase. In fact, in 2010, the simulated US women's LFPR would have ranked them $11^{\text {th }}$ among the 22 countries shown in Table 1 , compared to their actual ranking of $17^{\text {th }}$. The last column answers our original question about whether policy changes can explain the reversal of US women's relative position. It shows that the actual female LFPR grew 12.9 percentage points more slowly in the United States than in the other countries over the 1990-2010 period. However, with the non-US policy variables, it would have grown 9.1 percentage points more slowly. Therefore, the policy changes shown in Table 2 can account for 3.8 percentage points (29 percent) of the deterioration in US women's relative LFPR, a substantial effect. Panel B shows that the model with child care spending yields similar results, with the policy changes explaining the same $29 \%$ of the fall in US women's relative LFPR over the 1990-2007 period. In particular, the effect of child care policies is very small as well as being statistically insignificant: the expansion of child care policies outside the United States (Table 2) only raised the female LFPR in those countries by 0.057 percentage points relative to the United States (about one half of one percent of the total relative gain in these countries). ${ }^{8}$

\section{Are US Women Really Falling Behind?}

While parental leave and part-time protection policies appear to raise women's labor force participation, it is plausible that the generous parental leave mandates and high incidence of part time work in most countries outside the United States reduce the likelihood that women will be able to enter high-level jobs, which generally require full-time, full-year, career-long commitments. This may operate on the supply side, if long leaves encourage women to stretch

\footnotetext{
${ }^{8}$ A similar exercise to that in Table 4 finds very small effects for men: US men's LFP rate fell 2-3 percentage points relative to that in other countries between 1990 and 2007 or 2010, with 0.6 percentage points of this decline accounted for the expansion of these policies in the other countries in both specifications.
} 
their leave time longer than they otherwise would ${ }^{9}$ and part-time protections encourage them to take part-time rather than full-time jobs. On the demand side, more generous leave policies and a higher incidence of part-time entitlements may lead employers to engage in statistical discrimination against women as a group, anticipating that women will take advantage of such opportunities. Thus, while the LFPRs of women in other countries have risen relative to the United States, such increases may have come at the expense of advancement once they are in the labor force.

Consistent with this reasoning, Table 2 showed that US women are far less likely to work part time than women in other countries. To further examine whether the package of policies in other OECD countries tends to increase part-time relative to full-time employment on net, we repeated the analyses in Tables 3 and 4 using the employment-to-population ratio (EPOP) and the part-time employment-to-population ratio (PTEPOP) as dependent variables. We found that the non-US averages of the policy variables did contribute to a higher level of both employment and part-time employment for women, but with most of the employment effect accounted for by part-time jobs. For example, using our 1990-2010 sample (i.e. not including the child care variable), in 2010, giving US women the non-US levels of the policy variables would have raised their EPOP by 7.2 percentage points (from 69.3 to 76.5 percent) and their PTEMPOP by 4.0 percentage points (from 9.1 to 13.1 percentage points). These results imply only a 3.0 percentage point gain in employment in full-time jobs. Thus, while the policies discussed above raise women's employment, this increase is made up largely (55\%) of part-time work. In the specification including the child care variable, the joint effect of the policies was to raise US women's employment in 2007 by 7.1 percentage points and their part-time employment by 5.0 percentage points, implying that fully $70 \%$ of employment increase was due to part-time jobs. ${ }^{10}$ Although some women may prefer the relative flexibility of part-time work, several studies have

\footnotetext{
${ }^{9}$ This is not necessarily inconsistent with our finding of a positive effect on the labor force participation of women in the full 25-54 year age group, though our results do suggest that, on net, the policies increase labor force attachment. Also, as noted previously, individuals are counted as employed when out on leave.

${ }^{10}$ Effects of the policies on men's employment and part-time employment were small.
} 
found a significant and large part-time wage penalty across a variety of countries (Bardasi and Gornick 2008; Manning and Petrongolo 2008; Matteazzi, Pailhé and Solaz 2012). ${ }^{11}$

In addition to having a much higher incidence of full-time work than women in other countries, women in the United States also tend to work in higher level positions than those in most other countries. Table 5 uses microdata from the 1998 and 2009 International Social Survey Programme (ISSP) to compare men's and women's incidence in high level occupations to those in 10 other OECD countries for which the ISSP had data in these two years (the countries are shown in the Table). The occupations are Managers, Professionals, and "Male Professionals”, which we define as Professionals minus pre-university teachers and nurses, two historically female dominated occupations requiring high levels of education (Blau, Ferber and Winkler 2010). The data show that women and men in the United States were virtually equally likely to be managers in both 1998 and 2009. In contrast, in the other countries, women were about half as likely as men to be managers (roughly a six percentage point gap). Women were more likely than men to be professionals both in the United States and, on average, in the other countries. However, the female advantage was much larger in the United States than elsewhere. And, in the United States, women were equally likely as men to be employed in Male Professions, while in the other countries, there was a 2.4-2.8 percentage point female shortfall (17-25 percent). Thus, in both years, women in the United States were in higher level occupations than women elsewhere. ${ }^{12}$

Consistent with the data in Table 5, we have found in earlier work that women in the United States rank higher relative to the male wage distribution than is the case in other countries (Blau and Kahn 1996). However, wage setting is much more highly centralized in most countries outside the United States, with an emphasis in Continental Europe and Australia on union contracts that raise wages at the bottom of the distribution. We have found that such

\footnotetext{
${ }^{11}$ These include Austria, Canada, Germany, Italy, Poland, the United Kingdom, and the United States, although Bardasi and Gornick (2008) did not find a part-time wage penalty in Sweden.

${ }^{12}$ International Labour Organisation data confirm that the United States has had a lower level of occupational segregation by gender than in most other Western industrialized countries (Anker 1998).
} 
policies lower the gender wage gap in such countries relative to the United States, although they also appear to raise women's relative unemployment rates (Blau and Kahn 1996 and 2003; Bertola, Blau and Kahn 2007). In addition, by reducing wage differentials associated with occupation or industry, centralized wage setting may reduce employed women's incentives to seek higher level positions compared to the United States.

\section{Conclusions}

Our analysis of women's labor force participation and family-friendly policies suggests that there may be a tradeoff between some policies that make it easier for women to combine work and family and women's advancement at work. Policies that encourage the taking long, paid parental leaves from work and give part-time work entitlements may give women options that they would not otherwise have had. However, such policies may also leave women less likely to be considered for high-level positions. One's evaluation of such policies must take both of these effects into account.

\section{References}

Anker, Richard. 1998. Gender and Jobs: Sex Segregation of Occupations in the World. Geneva: International Labour Office.

Bardasi, Elena, and Janet C. Gornick. 2008. “Working for Less? Women’s Part-Time Wage Penalties Across Countries.” Feminist Economics 14(1): 37-72.

Belkin, Lisa. 2003. “The Opt-Out Revolution.” New York Times (October 26), http://www.nytimes.com/2003/10/26/magazine/26WOMEN.html?pagewanted=all (accessed Sept. 6, 2012).

Bertola, Giuseppe, Francine D. Blau, and Lawrence M. Kahn. 2007. “Labor Market Institutions and Demographic Employment Patterns.” Journal of Population Economics 20(4): 833-867. Blau, Francine D., Marianne A. Ferber, and Anne E. Winkler. 2010. The Economics of Women, Men, and Work, $6^{\text {th }}$ edition. Upper Saddle River, N. J.: Prentice Hall. Blau, Francine D., and Lawrence M. Kahn. 1996. "Wage Structure and Gender Earnings Differentials: An International Comparison.” Economica, 63(250S): S29-S62. 
Blau, Francine D., and Lawrence M. Kahn. 2003. “Understanding International Differences in the Gender Pay Gap.” Journal of Labor Economics 21(1): 106-144.

Goldin, Claudia. 1995. “The U-Shaped Female Labor Force Function in Economic

Development and Economic History.” In Schultz, T. Paul, ed., Investment in Women’s Human

Capital. Chicago: University of Chicago Press, pp. 61-90.

Gruber, Jonathan. 2011. Public Finance and Public Policy, $3^{\text {rd }}$ edition. New York: Worth Publishing.

Mammen, Kristin and Christina Paxson. 2000. "Women’s Work and Economic Development.” Journal of Economic Perspectives 14(4): 141-164.

Manning, Alan, and Barbara Petrongolo. 2008. “The Part-Time Pay Penalty for Women in Britain.” Economic Journal 118 (526): F28-F51.

Matteazzi, Eleonora, Ariane Pailhé, and Anne Solaz. 2012. “Part-Time Wage Penalties in Europe: A Matter of Selection or Segregation?” Society for the Study of Economic Inequality Working Paper ECINEQ WP 2012-250.

Max Planck Institute for Demographic Research. 2012. “Comparative Family Policy Database.” http://www.demogr.mpg.de/cgi-bin/databases/FamPolDB/index.plx (accessed April 26, 2012).

Nickell, Stephen. “Unemployment and Labor Market Rigidities: Europe versus North America.” Journal of Economic Perspectives 11(3): 55-74.

OECD. 2010a. OECD Employment Outlook 2010. Paris: OECD.

OECD. 2010b. “Detailed Description of Part-Time Work Regulations and Unemployment Benefit Schemes Affecting Part-Time Workers: Supporting Material for Chapter 4 'How Good is Part-Time Work?’ of the 2010 OECD Employment Outlook.” Paris: OECD.

OECD. 2012. “OECD Online Employment Database.” http://www.oecd.org/els/employmentpoliciesanddata/onlineoecdemploymentdatabase.htm (accessed April 26, 2012).

OECD. Various Issues. Taxing Wages. Paris: OECD. 
Ruhm, Christopher J. 1998. “The Economic Consequences Of Parental Leave Mandates: Lessons From Europe.” Quarterly Journal of Economics 113(1): 285-317.

United Nations (UN) Department of Economic and Social Affairs, Population Division. 2011. World Population Prospects: The 2010 Revision, CD-ROM Edition.

Waldfogel, Jane. 1998. “The Family Gap for Young Women in the United States and Britain:

Can Maternity Leave Make a Difference?” Journal of Labor Economics 16(3): 505-545.

Waldfogel, Jane. 2001. “Family and Medical Leave: Evidence from the 2000 Surveys,” Monthly Labor Review 124 (9): 17-23. 
Table 1: Male and Female Labor Participation Rates, Individuals Age 25-54, 1990 and 2010

\begin{tabular}{|c|c|c|c|c|}
\hline \multirow[t]{2}{*}{ Country } & \multicolumn{2}{|c|}{ Men } & \multicolumn{2}{|c|}{ Women } \\
\hline & 1990 & 2010 & 1990 & 2010 \\
\hline Australia & 93.3 & 90.6 & 66.8 & 75.2 \\
\hline Austria & 93.1 & 92.5 & 71.6 & 82.8 \\
\hline Belgium & 92.2 & 92.2 & 60.8 & 80.4 \\
\hline Canada & 93.1 & 90.5 & 75.5 & 82.3 \\
\hline Denmark & 94.5 & 92.4 & 87.8 & 85.6 \\
\hline Finland & 92.9 & 90.6 & 86.4 & 84.4 \\
\hline France & 95.6 & 94.2 & 72.2 & 83.8 \\
\hline Germany & 90.2 & 93.1 & 63.4 & 81.3 \\
\hline Greece & 94.3 & 94.2 & 51.5 & 72.2 \\
\hline Ireland & 91.8 & 89.9 & 45.4 & 72.2 \\
\hline Japan & 97.5 & 89.4 & 64.2 & 64.4 \\
\hline Italy & 94.1 & 96.2 & 53.9 & 71.6 \\
\hline Luxembourg & 95.0 & 94.8 & 49.7 & 76.4 \\
\hline Netherlands & 93.4 & 93.3 & 58.5 & 82.3 \\
\hline New Zealand & 93.5 & 91.8 & 69.2 & 76.9 \\
\hline Norway & 92.3 & 90.2 & 79.2 & 84.4 \\
\hline Portugal & 94.3 & 92.5 & 69.4 & 84.9 \\
\hline Spain & 94.4 & 92.5 & 46.9 & 78.3 \\
\hline Sweden & 94.7 & 93.6 & 90.7 & 87.5 \\
\hline Switzerland & 98.2 & 95.7 & 73.7 & 83.4 \\
\hline United Kingdom & 94.8 & 91.4 & 73.0 & 78.7 \\
\hline United States & 93.4 & 89.3 & 74.0 & 75.2 \\
\hline Non-US Average & 94.0 & 92.5 & 67.1 & 79.5 \\
\hline US Rank of 22 & 14 & 22 & 6 & 17 \\
\hline
\end{tabular}

Source: OECD Online Employment Database at:

http://www.oecd.org/els/employmentpoliciesanddata/o nlineoecdemploymentdatabase.htm Notes: Data for Austria refer to 1994 and 2010 and for Switzerland to 1991 and 2010. 
Table 2: Selected Labor Market Policies and Part-Time Work Incidence, US and Average of 16 Non-US OECD Countries

\begin{tabular}{|c|c|c|c|c|}
\hline & \multicolumn{2}{|r|}{1990} & \multicolumn{2}{|r|}{2010} \\
\hline & US & Non-US Average & US & Non-US Average \\
\hline Parental Leave: Weeks & 0 & 37.2 & 12 & 57.3 \\
\hline Parental Leave: Replacement Rate & & & & \\
\hline (including zeros) & 0 & 26.5 & 0 & 38 \\
\hline Right to Part Time Work (1=yes) & no & 0 & no & 0.313 \\
\hline Equal Treatment, Part Time & & & & \\
\hline Workers (1=yes) & no & 0.125 & no & 0.750 \\
\hline Public Child Care Spending (per & & & & \\
\hline child 0-4/GDP)*1000 & 0 & 1.614 & 0 & 1.763 \\
\hline Male Part Time Work Incidence & 0.028 & 0.031 & 0.039 & 0.051 \\
\hline Female Part Time Work Incidence & 0.147 & 0.258 & 0.131 & 0.260 \\
\hline
\end{tabular}

Sources: Data are from the Max Planck Institute for Demographic Research, Comparative Family Policy Database, available at http://www.demogr.mpg.de/cgibin/databases/FamPoIDB/index.plx ; OECD Social Expenditures Data Base available at http://stats.oecd.org/ ; OECD (2010a and b); the OECD Online Employment Database; and UN (2011).

Notes: Child care data are for 1990 and 2007. Non-US countries include:

Belgium, Canada, Denmark, Finland, France, Germany, Greece, Ireland, Italy, Luxembourg, Netherlands, New Zealand, Norway, Portugal, Spain, and the UK. Part-time work is defined as less than 30 hours per week. 
Table 3: Selected Regression Results for Labor Force Participation, Age 25-54

\begin{tabular}{|c|c|c|c|c|}
\hline & Men & Women & Men-Women & $\begin{array}{c}\text { Log Ratio } \\
\text { Men/Women }\end{array}$ \\
\hline \multicolumn{5}{|l|}{ A. Years 1990-2010 } \\
\hline Parental Leave: Weeks & $\begin{array}{c}0.018^{*} \\
(0.008)\end{array}$ & $\begin{array}{c}0.041 \\
(0.050)\end{array}$ & $\begin{array}{l}-0.023 \\
(0.048)\end{array}$ & $\begin{array}{l}-0.000 \\
(0.001)\end{array}$ \\
\hline \multicolumn{5}{|l|}{ Parental Leave: } \\
\hline Replacement Rate & $\begin{array}{c}0.003 \\
(0.003)\end{array}$ & $\begin{array}{c}0.045 \\
(0.032)\end{array}$ & $\begin{array}{l}-0.043 \\
(0.033)\end{array}$ & $\begin{array}{l}-0.001 \\
(0.001)\end{array}$ \\
\hline Right to Part-Time Work & $\begin{array}{c}0.462 \\
(0.369)\end{array}$ & $\begin{array}{l}4.304^{*} \\
(1.989)\end{array}$ & $\begin{array}{l}-3.842+ \\
(1.962)\end{array}$ & $\begin{array}{l}-0.059+ \\
(0.033)\end{array}$ \\
\hline \multicolumn{5}{|l|}{ Equal Treatment, Part-Time } \\
\hline Workers & $\begin{array}{l}0.406^{*} \\
(0.194)\end{array}$ & $\begin{array}{l}2.281+ \\
(1.244)\end{array}$ & $\begin{array}{l}-1.875 \\
(1.211)\end{array}$ & $\begin{array}{c}-0.039+ \\
(0.020)\end{array}$ \\
\hline Male Unemp. Rate & $\begin{array}{l}-0.021 \\
(0.043)\end{array}$ & $\begin{array}{c}0.194 \\
(0.262)\end{array}$ & $\begin{array}{l}-0.215 \\
(0.240)\end{array}$ & $\begin{array}{l}-0.002 \\
(0.004)\end{array}$ \\
\hline \multicolumn{4}{|l|}{ F Test: parental leave } & $p=0.0166$ \\
\hline policies & $p=0.0005$ & $p=0.1205$ & $p=0.2359$ & $p=0.2237$ \\
\hline F Test: part-time policies & $p=0.0718$ & $p=0.0099$ & $p=0.0276$ & $p=0.0165$ \\
\hline $\mathrm{N}$ & 424 & 424 & 424 & 424 \\
\hline R squared & 0.872 & 0.921 & 0.934 & 0.911 \\
\hline \multicolumn{5}{|l|}{ B. Years 1990-2007 } \\
\hline Parental Leave: Weeks & $\begin{array}{l}0.020^{*} \\
(0.008)\end{array}$ & $\begin{array}{c}0.043 \\
(0.044)\end{array}$ & $\begin{array}{l}-0.023 \\
(0.042)\end{array}$ & $\begin{array}{l}-0.000 \\
(0.001)\end{array}$ \\
\hline \multicolumn{5}{|l|}{ Parental Leave: } \\
\hline Replacement Rate & $\begin{array}{c}0.002 \\
(0.003)\end{array}$ & $\begin{array}{c}0.041 \\
(0.033)\end{array}$ & $\begin{array}{l}-0.038 \\
(0.034)\end{array}$ & $\begin{array}{l}-0.001 \\
(0.001)\end{array}$ \\
\hline Right to Part-Time Work & $\begin{array}{c}0.382 \\
(0.377)\end{array}$ & $\begin{array}{l}3.343+ \\
(1.626)\end{array}$ & $\begin{array}{l}-2.961+ \\
(1.512)\end{array}$ & $\begin{array}{l}-0.046+ \\
(0.026)\end{array}$ \\
\hline \multicolumn{5}{|l|}{ Equal Treatment, Part-Time } \\
\hline Workers & $\begin{array}{l}0.458^{*} \\
(0.194)\end{array}$ & $\begin{array}{l}2.113+ \\
(1.156)\end{array}$ & $\begin{array}{l}-1.655 \\
(1.109)\end{array}$ & $\begin{array}{c}-0.036+ \\
(0.019)\end{array}$ \\
\hline \multicolumn{5}{|l|}{ Public Child Care Spending } \\
\hline$($ per child 0-4/GDP)*1000 & $(0.083)$ & (1.074) & $(1.027)$ & $(0.016)$ \\
\hline Male Unemp. Rate & $\begin{array}{c}0.009 \\
(0.048)\end{array}$ & $\begin{array}{c}0.022 \\
(0.322)\end{array}$ & $\begin{array}{l}-0.013 \\
(0.298)\end{array}$ & $\begin{array}{c}0.001 \\
(0.005)\end{array}$ \\
\hline $\begin{array}{l}\text { F Test: all policy variables } \\
\text { F Test: parental leave }\end{array}$ & $p=0.0032$ & $p=0.0131$ & $p=0.0279$ & $p=0.0097$ \\
\hline policies & $p=0.0006$ & $p=0.1175$ & $p=0.2661$ & $p=0.2467$ \\
\hline F Test: part-time policies & $p=0.0510$ & $p=0.0084$ & $p=0.0199$ & $p=0.0124$ \\
\hline $\mathrm{N}$ & 359 & 359 & 359 & 359 \\
\hline R squared & 0.879 & 0.934 & 0.948 & 0.928 \\
\hline
\end{tabular}

Notes: $+p<.10 ;{ }^{*} p<.05$. Standard errors clustered by country. Models include year and country dummies. 
Table 4: Effect of Parental Leave, Part-time Work and Child Care Policies on US - Non-US Differences in Women's LFPRs

\begin{tabular}{lccc}
\hline A. Child Care Variable Not In Model & 1990 & 2010 & Change \\
\hline & & & \\
US Actual & 73.97 & 75.21 & 1.24 \\
Non-US Actual & 65.16 & 79.28 & 14.11 \\
US with Non-US Policy Variables & 76.99 & 82.00 & 5.01 \\
US - Non-US Actual & 8.81 & -4.06 & -12.87 \\
US with Non-US Policies - Non-US Actual & 11.83 & 2.72 & -9.11 \\
& & & \\
\hline B. Child Care Variable In Model & 1990 & 2007 & Change \\
\hline & & & \\
US Actual & 73.97 & 75.37 & 1.40 \\
Non-US Actual & 65.16 & 77.99 & 12.82 \\
US with Non-US Policy Variables & 77.53 & 82.19 & 4.66 \\
US - Non-US Actual & 8.81 & -2.62 & -11.43 \\
US with Non-US Policies - Non-US Actual & 12.37 & 4.20 & -8.16 \\
\hline
\end{tabular}

Notes: Non-US countries are listed in Table 2. 
Table 5: Incidence of Managerial, Professional and "Male" Professional Jobs, US and 10 Other OECD Countries

\begin{tabular}{lcccccc}
\hline & \multicolumn{3}{c}{1998} & \multicolumn{3}{c}{2009} \\
\cline { 2 - 7 } & Men & Women & Men-Women & Men & Women & Men-Women \\
\hline US & & & & & & \\
Managers & 0.144 & 0.144 & 0.000 & 0.150 & 0.140 & 0.010 \\
Professionals & 0.148 & 0.219 & -0.071 & 0.161 & 0.243 & -0.081 \\
"Male" Professionals & 0.125 & 0.118 & 0.007 & 0.141 & 0.139 & 0.003 \\
& & & & & & \\
Non-US Average & & & & & & \\
Managers & 0.120 & 0.060 & 0.060 & 0.122 & 0.059 & 0.063 \\
Professionals & 0.140 & 0.152 & -0.012 & 0.170 & 0.189 & -0.019 \\
"Male" Professionals & 0.111 & 0.084 & 0.028 & 0.145 & 0.121 & 0.024 \\
\hline
\end{tabular}

Source: 1998 and 2009 International Social Survey Programme microdata. "Male" professionals are professionals excluding nurses and pre-university teachers. Non-US countries include Australia, Austria, Denmark, France, New Zealand, Norway, Portugal, Spain, Sweden and Switzerland. 